\title{
Perspectives
}

\section{The Ins and Outs of ESL in Canada: How the Past Can Inform the Future}

\section{Tracey M. Derwing}

For some people, nothing sounds duller than the word "history." And yet history can be fascinating; it can afford us a chance to see the world through others' eyes; in comparing historical events with the current state of affairs, we can sometimes perceive our realities in a new light. Landmarks in the history of English as a second language (ESL), including patterns of immigration, language policies, funding, curriculum choices, standards, and advocacy, are chronicled in this article. These issues are the lifeblood of our field and go back further than many people recognize. They are all influenced by personalities, ethics, and circumstances. In 1899, Frontier College started sending labourer-teachers to work camps, where they taught not only literacy but also ESL to immigrant workers in mines and on railroads. A century ago, handbooks were developed for instructors of "new Canadians." Since those early days, Canada has developed the most comprehensive system of adult ESL training in the world, and has produced internationally recognized research on second language acquisition. Furthermore, ESL teachers created professional organizations at the provincial/territorial and national levels. Some of the developments of TESL Canada will be examined here. In looking back, we can see how far we have come, and also get some sense of where the future will take us.

Pour certaines personnes, rien de plus assommant que le mot " histoire ». Et pourtant, l'histoire peut être un domaine fascinant qui nous offre la chance de voir le monde avec le regard des autres et peut-être envisager l'état actuel des choses sous un angle nouveau en comparant notre réalité aux évènements historiques. Cet article décrit des jalons de l'histoire de l'anglais comme langue seconde (ALS), y compris les tendances en immigration, les politiques linguistiques, le financement, les choix de programmes, les normes et les revendications. Ces enjeux représentent des éléments essentiels de notre domaine et ils remontent plus loin que plusieurs personnes imaginent. Ils ont tous été marqués par des personnages, des principes éthiques et des circonstances. En 1899, le Collège Frontière a commencé à envoyer des ouvriers-enseignants dans les chantiers pour enseigner la lecture et l'écriture ainsi que l'ALS aux travailleurs immigrants auvrant dans les mines et pour le chemin de fer. On a développé, il y a un siècle, des guides pour ceux qui enseignaient aux «nouveaux Canadiens ». Depuis lors, le Canada a développé le système le plus complet au monde visant la formation en ALS pour adultes et a 
produit de la recherche sur l'acquisition des langues secondes qui est reconnue à l'échelle internationale. De plus, les enseignants d'ALS ont créé des organisations professionnelles aux niveaux provincial, territorial et national. Nous nous pencherons sur certains éléments de l'évolution de TESL Canada. En jetant un coup d'œil vers l'arrière, nous constatons la distance parcourue et nous nous faisons une idée de ce que l'avenir nous réserve.

KEYWORDS: TESL Canada, history of ESL, immigration

I was invited by TESL Canada to present a keynote on the evolution of English language teaching in Canada and to make observations on the TESL Canada Federation. What follows is an abbreviated version of that presentation, given in June 2017 at the TESL Canada Conference in Niagara Falls. After this manuscript was submitted, TESL Canada announced that it would be suspending all services and closing its office. I have written a postscript to this paper, but have left the information about TESL Canada in the paper itself to be true to the content of the keynote presentation.

Between 1870 and 1913 Canada experienced rapid economic development. The railways were built to secure British Columbia's participation in Confederation and to open up the west. The government designed land policies to attract newcomers, but there was a concern about the "quality" of immigrants. Many Chinese labourers had worked on the railroads and wanted their families to join them, but in 1885 Canada imposed a stringent head tax to significantly restrict Chinese from immigrating. Not content with limiting Chinese newcomers, in 1897 the government passed the Alien Labour Act, to keep railways from importing too many "aliens." The 1910 Immigration Act gave Cabinet the power to refuse immigrants "belonging to any race deemed unsuited to the climate or requirements of Canada, or of immigrants of any specified class, occupation or character" (Green \& Green, 1996, p. 5). Moreover, Cabinet declared publicly that they would recruit farmers, farm workers, and female domestics from Britain, the United States, and northwestern Europe, but in fact, the government made arrangements with the CPR and other businesses to recruit labour from anywhere in Europe. Although the stated aim was to populate the west, people went to all regions of Canada (Green \& Green, 1996). Thus English language teaching was needed throughout the country.

Immigration dipped significantly between 1914 and 1918 during World War I. Canada sent more people to Europe than they brought in: 61,000 Canadians were killed overseas, and 424,000 served overseas (Canadian War Museum, n.d.). But in 1919, the war over, it was back to business as usual. The government made more revisions to the 1910 Immigration Act to gain even more control. They expanded their power over numbers and the ethnic composition of immigrants, all in an effort to ensure "quality" newcomers. 
So where does English language training fit in? The earliest formal training began with Frontier College, the well-known national literacy organization. Frontier College was founded by Reverend Alfred Fitzpatrick, who sent teachers to logging camps, railway lines, and other worksites to help with both literacy for Canadian-born workers and ESL for immigrants (www.frontiercollege.ca, n.d.). Fitzpatrick also published a Handbook for New Canadians in 1919. Just one year before, James Anderson had produced The Education of the New Canadian: A Treatise on Canada's Greatest Educational Problem (1918). The problem, in Anderson's view, was too many immigrants from less desirable regions, such as Ukraine and southern Europe. Anderson wasn't against all newcomers, as indicated here:

There is no finer type of foreign immigrant to Canada than the Scandinavians. They are a close second, indeed if not equal, to the British and American immigrants. The Scandinavians readily become assimilated to the new life of the Dominion; a very large proportion of them naturalize. They make frugal, industrious citizens, an asset to any young country. (1918, p. 200)

About the Chinese he said,

Gambling seems to be a besetting vice of Chinese, probably due to their social isolation. But on the whole, the Chinese are industrious, inoffensive and well behaved. Their industry would make them a splendid asset, but race antipathy has decreed that Canada shall never have a large influx from China. (1918, p. 221)

Anderson would be shocked to see that the Chinese now constitute one of Canada's largest immigrant groups. Like Anderson, Fitzpatrick thought the primary goal of educators was to assimilate newcomers. He argued,

the task of assimilating so many diverse peoples is a slow one.... in the interest of the rising generation and those unborn, it is incumbent upon us that assimilative forces be carefully and expeditiously set to work. The children in the public schools of today will be the fathers and mothers of the next generation, and it is essential that the former be given an insight into our Canadian life and ideals, so that they in turn may impart these to their offspring. (Fitzpatrick, 1919, p. 238)

This sounds somewhat like the proposed Charter of Values that the Parti Québécois tried to introduce in 2013. These ideas have been around for a long time. In fact perhaps Anderson, Fitzpatrick, and others felt even more threatened than some people do today, because of the enormity of immigration in those early years (see Figure 1). Figure 1 shows us that 1913 saw more immigration than any other time in our history; 400,000 people arrived. However, Canada's population in 1913 was just over 7,500,000, much smaller than the current $35,000,000$; thus the impact of immigration at the beginning of the last century was profound. 


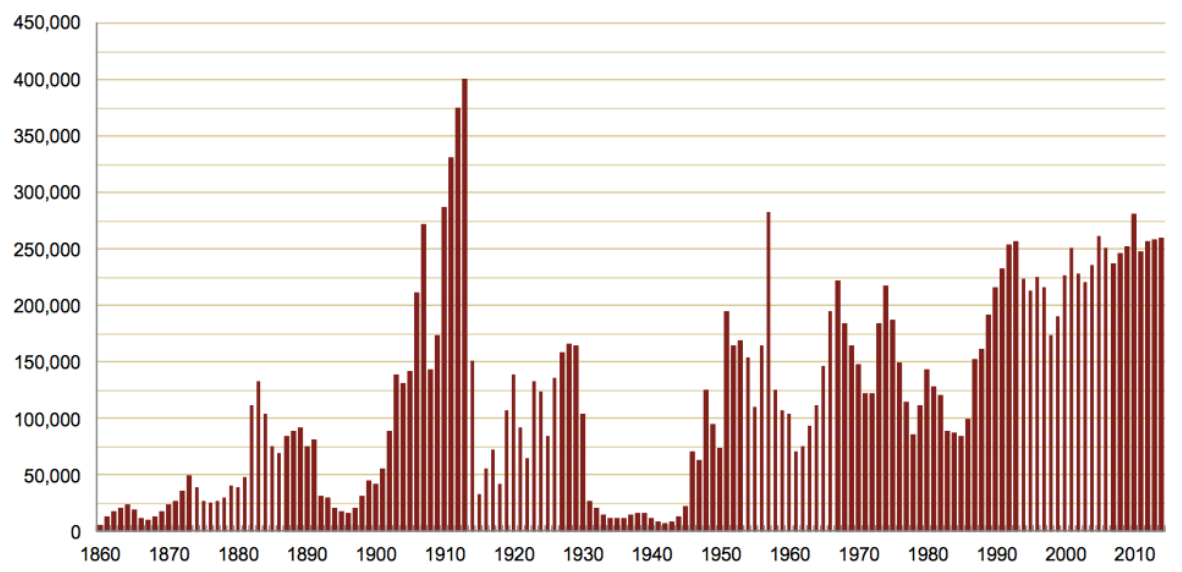

Figure 1: Permanent residents, 1860-2014 (Citizenship and Immigration Canada, 2014, p. 2)

So, in the early 1900s, immigrants learned English and "Canadian values" if there were classes where they lived or if they worked where Frontier College sent volunteer teachers. And then immigration dried up. Canada stopped admitting newcomers because much of the country itself had dried up, literally. Farms were knee-deep in dust during the Great Depression and unemployment was at an all-time high. Then World War II started and Canada not only limited immigration severely, but, appallingly, also interned Japanese Canadians. Figure 1 shows that fewer people were admitted to the country during this period than any time in our history. This was not our shining hour as a nation; not only did we intern citizens, but when 907 Jews boarded a ship to seek sanctuary from the Nazis, Canada refused to admit them. None is too many, said one of the border agents - also the view of our leaders at the time (Abella \& Troper, 2012).

When the war ended, Canada's leaders saw the country as increasingly independent of Britain, especially because of the winning performance of the Canadian military in Europe. Immigration recommenced, and a Citizenship Act was passed 1947. Since the days of Anderson and Fitzpatrick it had been assumed that learning an official language would lead to assimilation or at least integration - the two became formally linked shortly after World War II. Paul Martin Sr. stressed the importance of federal involvement in citizenship education for adult immigrants: "Apart from the purely legal consequences of acquiring a new citizenship, we must remember that in a democracy there are obligations and responsibilities upon a citizen, and these should be thoughtfully explained to those who join us" (Joshee \& Derwing, 2005, p. 63). This marked a change from the clear "us and them" mentality to working toward seeing newcomers as belonging to "us." Almost immediately after the act was 
passed, citizenship education was subsumed under second language instruction for newcomers.

The federal government started a transfer payment program to the provinces called Citizenship Instruction and Language Textbook (CILT) agreements. The intent of this funding was clear, but following a review conducted decades later, the federal government ended the CILT payments in 1989 because the funds were not being used for the intended purpose; moreover, the payments had no ceiling. There was no real oversight for all those years, but the federal government had assumed that the language classes it funded provided citizenship instruction (Joshee, 1996).

The 1960s brought major changes to Canada: the Bill of Rights was introduced and several other changes took place to make Canada more equitable. In 1962 the government introduced a modification to alter immigration substantially: people were chosen on the basis of their skills rather than their nationality (Derwing \& Munro, 2007). This was the first step toward a less racist immigration policy.

Language became a huge issue in the late 1950s and early 1960s, with the Quiet Revolution in Quebec. Quebeckers had legitimate complaints and were talking of separation. In 1963, the federal government established the Bilingualism and Biculturalism (B\&B) Commission, which travelled across the country listening to citizens discuss the role of the two "founding races"English and French (Derwing \& Munro, 2007). The irony, of course, is that the real founding peoples, Indigenous nations, were entirely left out. Also treated as an afterthought were the descendants of immigrants whose ancestry was neither English nor French. The Commission recommended that Ontario, Quebec, and New Brunswick become officially bilingual; only New Brunswick did so. It also recommended that English and French be declared the official languages of Canada, which happened in 1969. The Commission heard from ethnic groups, notably that "greatest Canadian educational problem," Ukrainians. They argued that their significant contributions to Canada should not be ignored. The findings of the Commission led to an awareness that immigrants from non-English and French backgrounds should be able to access heritage language programs (Derwing \& Munro, 2007).

In 1971, Pierre Trudeau introduced a multiculturalism policy to support the development of ethno-cultural groups and to assist new Canadians in acquiring an official language; in 1988, the policy became law when the Multiculturalism Act was passed. A few years before the policy was introduced, the Department of Manpower and Immigration initiated an English language program aimed at principal breadwinners: another word for "men." The program entailed a living allowance in addition to classes focused on preparation for employment. But when married couples entered the country ("married couples" meant a man and a woman at that time), they would be asked who the principal breadwinner was. Usually women deferred to their husbands, but in fact it was often women who first secured employment (Derwing \& 
Thomson, 2005). Settlement Language Programs (SLPs) were introduced in the 1980s to give support to the many newcomers who could not access other language instruction; Manitoba showed leadership in this area. SLPs had very little funding, but they addressed a pressing need (Burnaby, 1998).

In 1990, the federal government gave Quebec control of settlement and language training in that province; funds are transferred from Ottawa such that Quebec controls French language training and settlement. Then, in 1991, something very strange happened. The federal government tried to convince the other provinces that they should take on settlement and language training for newcomers. The federal government would devolve responsibility while supplying the funds. Both British Columbia and Manitoba agreed, while the rest of Canada continued to work directly with the federal government. In British Columbia there was a panic initially, because the province put the money provided by the federal government directly into their general coffers, and gave just a portion to the settlement agencies and language providers, but that was eventually straightened out.

1992 saw the implementation of Language Instruction for Newcomers to Canada (LINC). Massive changes grew out of the Immigrant Language Training Policy Framework, developed by the federal government, which was intended to:

- provide more immigrants with access to language training

- foster greater consistency of access and quality

- maximize cost-effectiveness of language training

- provide greater flexibility within programs to meet varied needs of clients

- develop greater cooperation and coordination among governments, NGOs, the private sector, and other partners

- incorporate information on Canadian values into training programs (Government of Canada, 1991b).

Initially, many were resistant to LINC; ATESL and TESL Ontario both submitted briefs protesting its implementation. The notion of opening LINC funding to a wide range of providers was viewed as a way of "cheaping out," as some entrepreneurs saw LINC as a financial opportunity with no need to pay instructors a living wage. The government indicated that it wanted programs to respond to diverse learner needs, but as time went on, private programs became increasingly similar. One issue that arose very early on was the government's conception of shared values.

[LINC] is a hegemonic force that operates to manage linguistic and hence, ethnic difference in a monolingual/bilingual nation-state that is threatened by linguistic (and "other") diversity ... The path that leads to "integration" through ESL instruction is littered with issues of identity, race and ethnicity, and assimilation that makes becoming "integrated" a much more complicated journey. (Cleghorn, 2000, p. 52) 
The federal government contracted consultants to produce Canada: A Source Book for Orientation, Language and Settlement Workers (Government of Canada, 1991a). This resource was intended to help language instructors and settlement workers convey Canadian values. It quickly fell out of favour: it was lambasted by ethnic groups and settlement agencies who found it condescending. They objected to statements such as "Urinating in public is illegal in Canada" (1991a, p. 107), implying that no Canadians perform this act. In fact, many Canadians do urinate in public, especially after hockey games. Furthermore, there were etiquette statements such as "most Canadians eating in a restaurant avoid making any noise when eating liquid foods such as soup" (p. 207). The book was withdrawn from shelves immediately because of its insulting nature. It was definitely an "us" versus "them" document, assuming that all Canadians behaved in certain ways and that all immigrants needed instruction on how to behave. Thomson and Derwing (2004), in a survey of LINC instructors, found that most teachers restricted "values" teaching to legal issues, gender equality, and respect for diversity. In fact, nearly a quarter of the instructors indicated that they didn't teach "values" at all, but focused exclusively on survival English.

Despite resistance, LINC was implemented, and programs went into curriculum development mode. The federal government was concerned that measurement of the progress of learners be consistent from one program or province to the next. A national working group was established to collect input from teachers, learners, and program directors on how best to do this. Ultimately the working group's findings were sent to Grazyna PawlikowskaWalentynowicz, who became the principal author of the first version of the Canadian Language Benchmarks (CLBs; 1996). Ongoing evaluation of the CLBs was conducted, and in 2000 Pawlikowska-Smith wrote a revised version.

In 1998, the Centre for Canadian Language Benchmarks was established. The Centre provides support in the implementation and dissemination of the Canadian Language Benchmarks and its corresponding French version. It conducts research projects on all things CLB, and in 2012 a fully validated update of the CLBs was issued. The CLBs constitute a massive endeavour. An offshoot of the CLBs is portfolio-based language assessment (PBLA). This is an approach to assessment designed to promote reflection on the part of the learner and the teacher, and to ensure that everyone understands where the learners' focus should be.

The 1990s and the 2000s saw a huge flurry of locally developed resources. At the risk of sounding like a homer, there are fantastic resources on the ATESL website (atesl.ca), many of which were funded by the Alberta government. All the provincial organizations, though, and several individual programs have made significant contributions, many of which are not on Tutela.ca, the online community for ESL/FSL professionals, funded by the federal government. It is worthwhile to keep up with what your neighbours 
are doing. Some wonderful resources were developed from the inception of LINC through the next two decades.

I want to come back to the issue of citizenship education, and the contentious issue of Canadian values. In 2011, Citizenship and Immigration Canada issued a new study guide for newcomers wanting to apply for citizenship, Discover Canada. The goal was to provide newcomers with a sense of Canadian values, although Discover Canada has been criticized for providing an overly conservative view of the country. For example, in its first edition, Jason Kenney, the Minister of Citizenship and Immigration at the time, insisted on the removal of a section on LGBQT rights (Canadian Press, 2010). Although many highly regarded Canadians contributed to the development of this guide, it is unsuitable for the intended audience. First, the average grade level of the document according to the Flesch-Kinkaid readability test was 12.4, much higher than a CLB 4. Moreover, at least one section was assessed at Grade 17 (Sallis, 2013). That far exceeds CLB 4, which is what the government requires for citizenship. Second, the guide is full of detail that has nothing to do with being a good Canadian citizen, such as the architectural styles of the various provincial legislatures. Research has shown that unnecessary detail has a deleterious effect on comprehension (Derwing, 1989). When the previous minister of Immigration, Refugees and Citizenship Canada (IRCC), John McCallum, was appointed in 2016, he indicated that the guide would be revised to be more readable and with less emphasis on the military (National Post, 2016). A new guide is in preparation (Kelli Fraser, personal communication). In the meantime, we have heard a lot more from politicians, especially Conservatives, about the need to ensure that immigrants know about and share Canadian values. Kellie Leitch, in her candidacy for leadership of the federal Conservative Party, produced a video in which she said the following:

There is a second part to my proposal. That is to screen all immigrants, refugees, and visitors to Canada for their agreement with Canadian values. Do they support the ideas of hard work, generosity, freedom, and tolerance? Do they believe men and women are equal? Do they agree that violence has no place in political disagreements? Do they agree that all should be left to worship as they see fit? ... These are the values that are enshrined in our constitution. (City News, 2017)

To me, this approach to looking for a "quality" immigrant is backwards; fortunately, it didn't sit well with most Canadians. In the days of Anderson and Fitzpatrick, the government was on their side, but our current government has more enlightened policies. And I think we can agree, as people who have considerable face-to-face contact with newcomers, most immigrants are hard working (although that is not written into the Charter as a requirement); they want to get on with their lives and have better lives for their children. 
Which leads to the question, what are Canadian values? I don't think that we as ESL teachers can define this, even though LINC expects that of us, except to note that Canadian values are the laws. We are not in a position to generalize beyond that. Of course, we can teach pragmatics (the culturally determined conventions of language) - and we should - but it is not up to us to go beyond the laws. Generosity and a hard-working nature are nice personal qualities, but many Canadian-born people are not generous and do not work hard. And these values are not in the Constitution. I will come back to this issue at the end.

To shift gears, I was asked by the conference organizers to talk about TESL Canada. In the interests of this historical account, I will say a few things about the association. A steering committee was struck in 1977 to write a draft constitution, which was passed in 1978. TESL Canada didn't become officially incorporated until 1984, but it was an entity, and the first national conference was held in 1979 (Eddy \& May, 2004). Originally, most of Canada was represented in the TESL Canada Federation; however, SPEAQ, Quebec's organization, withdrew in 1988, arguing that the focus on English for newcomers did not fit with the population of English language learners in Quebec. In 2015, TESL Ontario and BC TEAL withdrew from the federation for a complex array of reasons, but in the last couple of years, TESL Canada has rewritten its bylaws and has developed a strategic plan to go forward (they appear on the website, tesl.ca). It would be wonderful if TESL Canada can once again become the organization it was at the outset, and that appears to be the goal. Let us start with the Six Principles document (TESL Canada, 1982).

A TESL Canada symposium was held in December 1980 to discuss the settlement of the Vietnamese "Boat People" who had been arriving in large numbers. Hundreds of issues and recommendations came out of the symposium, which fell to an action committee to pull together. The committee produced the Six Principles document, which they presented to policy makers in response to the inadequacies of ESL provision. This document is well worth reading; much of it has strong relevance today, and it is a thoughtful, idealistic, and humane view of ESL provision for newcomers.

These are the principles taken from the document:

- accessibility to ESL for all newcomers

- flexibility and sufficiency

- national, provincial, and local coordination

- support for community agencies

- functional Canadian orientation and citizenship content in ESL material

- recognition of key roles of the ESL professional and the ESL profession (1982, p. 3).

Six Principles makes for sobering reading because it shows that in 2017 we still deal with some of the same issues faced 35 years ago. However, progress has been made. Let us consider the last of these principles, the recognition of 
the key roles of the ESL professional and the ESL profession. ESL professionals have fought for a long time to be recognized. In 1994, TESL Nova Scotia decided to do some research on accreditation of English language instructors. Dianne Keevil-Harrold (1995) undertook a comparison of two provinces, British Columbia and Alberta, both of which had already been through an accreditation process, although they took very different steps to get there. In response to her extremely clear outlining of the accreditation process, which is documented in the TESL Canada Journal, Nova Scotia's members decided to institute an accreditation process themselves, as did Saskatchewan's. Eventually TESL Canada assumed the role of accreditation and also developed program standards. Of course there have been bumps along the way, but we have made significant progress from the days when this principle was proposed.

I just mentioned the TESL Canada Journal, which is one of the most outstanding contributions of TESL Canada to its membership. In preparing for this presentation, I consulted the archives of the journal, which began in 1984. It is a veritable who's who of people involved in language learning and teaching in Canada. The TESL Canada Journal is a refereed publication, and many of its articles have been widely cited in other international journals. Because it is open access, anyone can go through the older volumes-and I recommend it - there are some jewels in there, and it also gives one a sense of shifting priorities over time. I want to make special note of the fact that all of the editors of the TCJ have been volunteers, and they all put in a tremendous amount of work that we should all be grateful for. Since the 1980s TESL Canada has also published a bulletin with updates on the association and the provincial affiliates.

As previously mentioned, the national conferences began in 1979, and were cohosted with a provincial association. In fact this is the first standalone TESL Canada conference. It behooves us to ask ourselves what the differences should be between national and provincial conferences. If it were just a matter of professional development, then why come to a national conference when provincial conferences are usually very satisfying, comprehensive, and collegial events? They tend to offer both opportunities to learn practical tips for the classroom and presentations on current research. Given that, why would a member of a provincial organization come to a national conference? There are good reasons to meet nationally, and we should try to capitalize on them to a greater extent. For instance, TESL Canada has introduced a 50-hour practicum requirement for TESL program recognition. Why not bring together a forum for accredited programs on how to cope with this new requirement, which for many represents a serious capacity problem? The national conference could be used to consult with members, not only at the AGM, where people may be reluctant to talk in the interests of time, but over the course of the two days, with special sessions dealing with issues that face providers across the country. TESL Canada has generally been 
an excellent forum for federal funders to present what their current projects are and what is planned for the future. Whenever I have gone to a federal presentation, it has always been standing room only. In future, TESL Canada might consider giving our federal partners a plenary slot, so that everyone can hear the directions that the government is considering. Moreover I think we might all consider two things that are listed on the TESL Canada website as part of our mandate-(a) excellence in language, settlement, and refugee programs and (b) linguistic rights for individuals and communities. To me, these sound like advocacy. The Six Principles document was a fine example of TESL Canada advocacy on behalf of immigrant learners. It came from the ground up. We might want to contemplate TESL Canada taking on some issues that the majority of the membership see as important. For instance, the immigrant transportation loan is a severe barrier to settlement for refugees, as a review by the government itself demonstrated (Citizenship and Immigration Canada, 2015). Not only that, we have witnessed inequitable treatment of refugees; some Syrians have had their travel costs waived while other refugees, including Syrians, did not. The loan program costs approximately $\$ 13$ million a year. That may seem like a lot of money to you and me, but for a federal budget it is a drop in the bucket. There is an appetite for leadership on this type of issue. When ATESL decided in January 2017 to ask its members to sign a petition to abolish the transportation loan, it wrote to other provincial associations and suggested that they do the same. The numbers of signatures from across the country rose immediately. So perhaps TESL Canada could survey its members to get a sense of their priorities. Nearly every week there is something in the news about issues that we as an association may want to weigh in on. Importantly, we as a group could have our voices heard much louder if we are together than if we stand alone.

English language instruction in Canada has come a long way. We have many accredited teachers who provide effective and efficient language training and excellent programs across the country. We have a strong research base on which to rely; Canada is recognized internationally for superb research focused on second language acquisition. We, as teachers, realize that learning is not all about language, and we can be responsive to the needs of the students. We know that one size does not fit all. But we as a collective still have issues to address; we need increased expertise as contexts shift. Our field would benefit from more collaborations across programs and sectors; ongoing, sustainable funding for successful pilot projects; shorter waiting lists; and a long list of other concerns-insert your own priority here.

I want to return to the issue of citizenship education. In a survey of LINC instructors carried out several years ago (Thomson \& Derwing, 2004), ESL teachers reported that they can't prepare learners for citizenship because of the low proficiency levels of their students; certainly many of the students are not at a level where they could read and process Discover Canada. However, 
the content in a study guide is not necessarily the approach to take. Teachers can still incorporate citizenship into their lessons, even at low proficiency levels. For example, Bonnie Nicholas from NorQuest in Edmonton routinely starts each course with the development of a class charter that she ties in with the Charter of Rights and Freedoms. The class decides together what the expectations of the classroom will be for students and instructor alike. This is the sort of innovative approach to "values" using the uppermost law of the land as a starting point. We can do this, and, in fact, we can take inspiration from a citizenship class offered in 1913. John Ralston Saul, in his book titled Reflections of a Siamese Twin (1997), shared a photo of a blackboard from a citizenship class for immigrants. On it were these duties of a citizen: "understand our government, take active part in politics, assist all good causes, lessen intemperance, and work for others" (p. 130). This is not a bad list. Perhaps we should be thinking about how we could encourage this in our classes as well as in our own association.

\section{PostScript}

On October 18, 2017, the TESL Canada Federation notified its members that it would be suspending services immediately due to a lack of funds and a resistance on the part of the membership to raise fees, although it hoped to maintain the organization itself. The past several years were very difficult for the Federation, so the possible demise of the association did not come as a complete surprise. However, it leaves several questions that we as ESL professionals must address. The immediate impact on programs and instructors has to do with issues of accreditation. Some provinces (e.g., ATESL) gave up their own accreditation procedures and must now consider reinstituting provincial accreditation or investigating private companies such as Orion. The future of the TESL Canada Journal is another major concern. The journal still has SSHRC funding, but it is unclear what will happen after this year. It is a fine resource, and it would be a shame to lose it. Most importantly, we now lack a national body to advocate on our behalf and on behalf of our students. This is all at a time when IRCC has decided to offer separate conferences for LINC instructors, thus further fragmenting our field. Of course, it is their right to do this, but it means that LINC and other ESL providers will have less contact and fewer opportunities to learn from each other. Our provincial organizations are now more important than ever, and yet some of them are struggling too. I know that everyone has a very busy life, and that teaching newcomers is demanding and emotion-filled. However, I encourage you to think about what you can do to ensure that the progress we in the ESL field have achieved in Canada is not lost. Many of the provincial associations are in touch with each other, but now it is time for them to talk and listen to all of us. And, at the time that this postscript is being written, the TESL Canada Board is hopeful that the organization will continue. Whether it does or not, 
we must come together to reimagine the best possible outcomes for our students and for ESL professionals.

\section{The Author}

Tracey Derwing has long had an interest in ESL, particularly factors that affect communication such as pronunciation and fluency. She was a Co-Director of the Prairie Metropolis Centre for 11 years, and undertook several studies of immigration and integration.

\section{Acknowledgements}

Several colleagues and friends have had a profound influence on my views of ESL, including Murray Munro, Marian Rossiter, Ron Thomson, Jennifer Foote, Erin Waugh, Jeff Bullard, Judy Cameron, Patti Dunne, Ron Smyth, Anna DeLuca, Carolyn Dieleman, and Martha Justus. I thank them all for their wisdom.

\section{References}

Abella, I., \& Troper, H. M. (2012). None is too many: Canada and the Jews of Europe, 1933-1948. Toronto, ON: University of Toronto Press.

Anderson, J. T. M. (1918). The education of the new Canadian: A treatise on Canada's greatest educational problem. London, UK: J.M. Dent \& Sons.

Burnaby, B. (1998). ESL policy in the US and Canada: Basis for comparison. In T. Ricento \& B. Burnaby (Eds.). Language and politics in the US and Canada: Myths and realities (pp. 246-264). Mahwah, NJ: Erlbaum.

Canadian Press. (2010). Gay rights section nixed for immigrants' guide; Immigration minister a past opponent of same-sex marriage. CBC News/Politics, March 2, 2010. http://www.cbc.ca/news/ politics/gay-rights-section-nixed-for-immigrants-guide-1.943866

Canadian War Museum. (n.d.). The cost of Canada's war. Retrieved June 14, 2017 from http://www. warmuseum.ca/firstworldwar/history/after-the-war/legacy/the-cost-of-canadas-war/

Citizenship and Immigration Canada. (2011). Discover Canada study guide: The rights and responsibilities of citizenship. Ottawa, ON: Government of Canada.

Citizenship and Immigration Canada. (2014). Canada facts and figures, immigrant overview, permanent residents, 2014. www.cic.gc.ca/english/pdf/2014-Facts-Permanent.pdf. Ottawa. ON: Government of Canada.

Citizenship and Immigration Canada (2015). Evaluation of the immigration loan program. Ottawa, ON: Citizenship and Immigration Canada.

City News (2017). Video: Kellie Leitch's video on Canadian values causes uproar on social media. Retrieved from http://www.citynews.ca/video/2017/02/27/video-kellie-leitchs-video-oncanadian-values-causes-uproar-on-social-media/

Cleghorn, L. (2000). Valuing English: An ethnography of a federal language training program for adult immigrants. Unpublished master's thesis, Ontario Institute for Studies in Education of the University of Toronto.

Derwing, T. M. (1989). Information type and its relation to nonnative speaker comprehension. Language Learning, 39, 157-172. http://doi.org/10.1111/j.1467-1770.1989.tb00420.x

Derwing, T. M., \& Munro, M. J. (2007). Canadian policies on immigrant language education. In R. Joshee \& L. Johnson (Eds.), Comparative multicultural education policies in Canada and the United States: Symbol and substance (pp. 93-106). Vancouver, BC: UBC Press.

Derwing, T. M., \& Thomson, R. I. (2005). Citizenship concepts in LINC classrooms. TESL Canada Journal, 23(1), 44-62. https://doi.org/10.18806/tesl.v23i1.77

Eddy, C., \& May, C. (2004). TESL Canada: National contributions to ESL professionalism in Canada. TESL Canada Journal, Special Issue \#4, 89-103. https://doi.org/10.18806/tesl.v0i0.1042 Fitzpatrick, A. (1919). Handbook for new Canadians. Toronto, ON: Ryerson Press. 
Frontier College. (n.d.). Our history. www.frontiercollege.ca/About-Us/History. Accessed June 15, 2017.

Government of Canada. (1991a). Canada: A source book for orientation, language and settlement workers. Ottawa, ON: Employment and Immigration Canada.

Government of Canada. (1991b). Immigrant language training policy framework. Internal document. Ottawa, ON: Immigration Policy and Program Development.

Green, A., \& Green, D. (1996). The economic goals of Canada's immigration policy, past and present. RIIM Working Paper Series, No. 96-04.

Joshee, R. (1996). The federal government and citizenship education for newcomers. Canadian and International Education, 25, 108-127.

Joshee, R., \& Derwing, T. M. (2005). The unmaking of citizenship education for adult immigrants to Canada. Journal of International Migration and Integration, 6(1), 61-80.

Keevil-Harrold, D. (1995). Accreditation/certification for adult ESL instructors in Canada: An overview. TESL Canada Journal, 13(1), 37-62. https://doi.org/10.18806/tesl.v13i1.660

National Post. (2016). Liberal minister hints citizenship guide's trumpeting of War of 1812 victory will be pared down (February 26, 2016). http://nationalpost.com/news/canada/liberal-minister-hints-citizenship-guides-trumpeting-of-war-of-1812-victory-will-be-pared-down/ wcm/808430ed-b22d-46fc-b359-e0b43bd9531d

Pawlikowska-Walentynowicz, G. (1996). The Canadian language benchmarks (working document). Ottawa, ON: Citizenship and Immigration Canada.

Pawlikowska-Smith, G. (2000). The Canadian language benchmarks (2000). Ottawa, ON: Citizenship and Immigration Canada.

Sallis, L. (2013). The use of Discover Canada: The rights and responsibilities of Canadian citizenship study guide in LINC classrooms. Unpublished capping project, Department of Educational Psychology, University of Alberta; Edmonton, Alberta.

Saul, J. R. (1997). Reflections of a Siamese twin: Canada at the end of the 20th century. New York, NY: Viking.

TESL Canada. (1982). The provision of E.S.L. training to adults: Six principles toward a national policy. TESL Canada Newsletter, 2(1), Spring.

Thomson, R. I., \& Derwing, T. M. (2004). Presenting Canadian values in LINC: The roles of textbooks and teachers. TESL Canada Journal, 22(2), 17-33. https://doi.org/10.18806/tesl.v21i2.172 